\title{
Dynamic regulation of the PR-Set7 histone methyltransferase is required for normal cell cycle progression
}

\author{
Shumin Wu, ${ }^{1}$ Weiping Wang, ${ }^{2}$ Xiangduo Kong, ${ }^{3}$ Lauren $M$. Congdon, ${ }^{1}$ Kyoko Yokomori, ${ }^{3}$ \\ Marc W. Kirschner, ${ }^{2}$ and Judd C. Rice ${ }^{1,4}$ \\ ${ }^{1}$ Department of Biochemistry and Molecular Biology, University of Southern California Keck School of Medicine, Los Angeles, \\ California 90033, USA; ${ }^{2}$ Department of Systems Biology, Harvard Medical School, Boston, Massachusetts 02115, USA; \\ ${ }^{3}$ Department of Biological Chemistry, School of Medicine, University of California at Irvine, Irvine, California 92697, USA
}

\begin{abstract}
Although the PR-Set7/Set8/KMT5a histone H4 Lys 20 monomethyltransferase (H4K20me1) plays an essential role in mammalian cell cycle progression, especially during G2/M, it remained unknown how PR-Set7 itself was regulated. In this study, we discovered the mechanisms that govern the dynamic regulation of PR-Set7 during mitosis, and that perturbation of these pathways results in defective mitotic progression. First, we found that PR-Set7 is phosphorylated at Ser 29 (S29) specifically by the cyclin-dependent kinase 1 (cdk1)/cyclinB complex, primarily from prophase through early anaphase, subsequent to global accumulation of H4K20me1. While S29 phosphorylation did not affect PR-Set7 methyltransferase activity, this event resulted in the removal of PR-Set7 from mitotic chromosomes. S29 phosphorylation also functions to stabilize PR-Set7 by directly inhibiting its interaction with the anaphase-promoting complex (APC), an E3 ubiquitin ligase. The dephosphorylation of S29 during late mitosis by the Cdc14 phosphatases was required for APC ${ }^{\text {dh1 }}$-mediated ubiquitination of PR-Set7 and subsequent proteolysis. This event is important for proper mitotic progression, as constitutive phosphorylation of PR-Set7 resulted in a substantial delay between metaphase and anaphase. Collectively, we elucidated the molecular mechanisms that control PR-Set7 protein levels during mitosis, and demonstrated that its orchestrated regulation is important for normal mitotic progression.
\end{abstract}

[Keywords: PR-Set7; APC; Cdk1; Cdc14; cell cycle; chromatin]

Supplemental material is available at http://www.genesdev.org.

Received August 19, 2010; revised version accepted September 24, 2010.

Eukaryotic cell division is tightly regulated by a strict order of temporal events. During mitosis, there are three essential mechanisms that govern these events: the phosphorylation of key substrates mediated by the cyclindependent kinases (CDKs), their subsequent dephosphorylation by certain phosphatases, and the degradation of target proteins mediated by the anaphase-promoting complex (APC), an E3 ubiquitin ligase (Sullivan and Morgan 2007). The mitotic CDKs drive early mitosis by phosphorylating critical downstream cell cycle regulators required for chromosome condensation, nuclear envelope breakdown, and mitotic spindle assembly. During late mitosis, the dephosphorylation of CDK substrates by certain phosphatases is critical for chromosome and spindle movements, spindle disassembly, and nuclei reformation. The APC governs progression into anaphase and beyond

${ }^{4}$ Corresponding author.

E-MAIL juddrice@usc.edu; FAX (323) 442-7857.

Article published online ahead of print. Article and publication date are online at http://www.genesdev.org/cgi/doi/10.1101/gad.1984210. by ubiquitinating key substrates, including mitotic cyclins and securin, resulting in their proteasome-mediated degradation, which triggers chromosome segregation (Peters 2006; Thornton and Toczyski 2006). Therefore, proper mitotic progression depends largely on the ordered phosphorylation, dephosphorylation, and degradation of key cell cycle regulatory proteins. Although several of these proteins have been identified, the discovery of novel proteins regulated by this pathway will provide important insights into the fundamental mechanisms of the eukaryotic cell cycle.

We previously codiscovered a histone-modifying enzyme, PR-Set7/Set8/KMT5a, that specifically monomethylates histone H4 Lys 20 (H4K20me1) (Fang et al. 2002; Nishioka et al. 2002). Subsequent studies demonstrated that PR-Set7-mediated H4K20mel is required for chromatin compaction and transcriptional repression of specific genes, including some involved in mammalian differentiation (Biron et al. 2004; Trojer et al. 2007; Kalakonda et al. 2008; Sims and Rice 2008). Recent studies indicate that PR-Set7 also plays an essential role in 
mammalian cell cycle progression (Karachentsev et al. 2005; Jorgensen et al. 2007; Tardat et al. 2007; Houston et al. 2008; Huen et al. 2008; Yin et al. 2008). The loss of PR-Set7 results in a G2 arrest in human cells, and PRSet $7^{-1-}$ mice are embryonic-lethal, arresting at the eightcell stage (Houston et al. 2008; Oda et al. 2009). PR-Set7 itself is tightly cell cycle-regulated, with its lowest levels observed during $S$ phase and peaking at G2/M, suggesting that the regulation of PR-Set7 is important for proper cell division (Rice et al. 2002). These collective findings strongly suggest that the dynamic regulation of PR-Set7 is essential for proper mammalian mitotic progression, although the underlying mechanisms responsible for its regulation remain unknown.

Since the Xenopus laevis ortholog of PR-Set7 was described previously to be a mitotic-specific phosphoprotein, we hypothesized that PR-Set7 phosphorylation is a critical event in its regulation during mitosis (Stukenberg et al. 1997). In this study, we discovered that Ser 29 (S29) of PR-Set7 is a major target of phosphorylation mediated specifically by the cdk1/cyclinB complex during prophase to early anaphase. While S29 phosphorylation does not alter PR-Set7 methyltransferase activity, this event results in the removal of PR-Set7 from mitotic chromosomes. In addition, S29 phosphorylation stabilizes PRSet7 during mitosis by directly inhibiting APC-mediated ubiquitination and proteasome-mediated degradation of PR-Set7. Furthermore, the rapid dephosphorylation of PR-Set7 in anaphase by the Cdc14 phosphatases is required for PR-Set7 degradation. Collectively, our findings elucidate a novel pathway that governs PR-Set7 regulation, and demonstrate that these events are required for normal cell division.

\section{Results}

S29 is a major phosphorylated residue of human PR-Set7

To determine if PR-Set7 is phosphorylated in human cells, total cell lysates from the HEK-293 kidney cell line were processed using a Qiagen Phosphoprotein Column that specifically retains phosphorylated proteins. Western analysis was performed on both the column-bound protein fraction and the unbound flowthrough using a PR-Set7-specific antibody that strongly detected phosphorylated PR-Set7 in as little as $1 \%$ of the total bound material (Fig. 1A). In contrast, the ubiquitously expressed UBC9 protein was detected only in the flowthrough. Similar experiments conducted in the K562 human myeloid cell line confirmed that PR-Set7 is phosphorylated in human cells (Supplemental Fig. 1). To validate these findings, a Flag-tagged PR-Set7 plasmid was ectopically expressed in HEK-293 cells, and the cell lysates were processed using a Qiagen Phosphoprotein Column as described above. Western analysis using a Flag antibody confirmed that the Flag-PR-Set7 protein is detected in the column-bound fraction and therefore is a target for phosphorylation in cells (Fig. 1B)

The $X$. laevis ortholog of PR-Set7 was shown previously to be phosphorylated specifically during mitosis, suggesting that the kinase responsible for PR-Set7 phosphorylation would be active during this phase of the cell cycle (Stukenberg et al. 1997). Consensus sequence analysis of PR-Set7 for such a kinase yielded only one site that fit this criterion: The sequence surrounding S29 was a perfect match for the cdk1/cyclinB complex (S/T-P-X-K/R) (Fig. 1C). To confirm that S29 is a target for phosphorylation
A
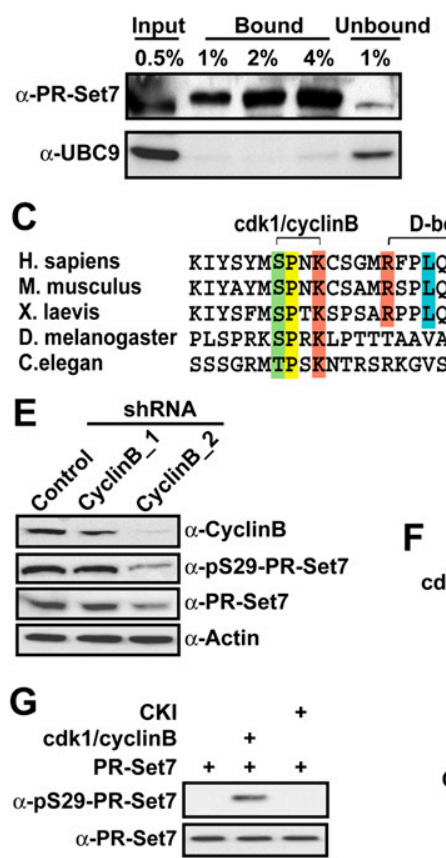

$\mathbf{F}$
B

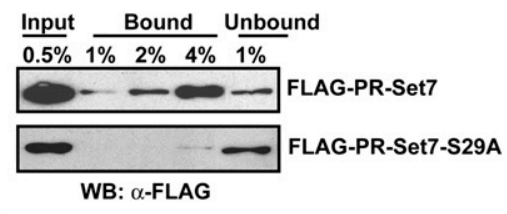

Input Bound Unbound $\begin{array}{lllll}0.5 \% & 1 \% & 2 \% & 4 \% & 1 \%\end{array}$ FLAG-PR-Set7-S29A WB: $\alpha-$ FLAG

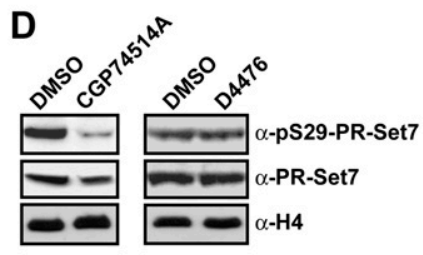
cdk1/cyclinB +++++ PR-Set7 WT WT N C N N-S29A

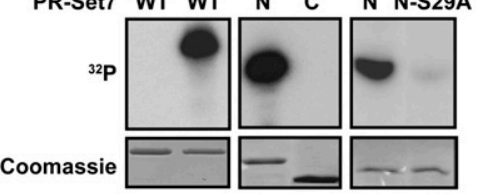

Figure 1. Cdk1/cyclinB phosphorylates S29 of PRSet7. (A) Phosphorylated proteins were isolated from cells using a phosphoprotein purification column. The indicated amounts of the input, column-bound, and unbound material were fractionated by SDS-PAGE prior to Western analysis. (B) HEK-293 cells expressing FlagPR-Set7 or S29A mutant were immunoprecipitated prior to phosphoprotein purification. Western analysis was performed using the indicated amounts of the input, column-bound, and unbound material. $(C)$ Peptide sequences of PR-Set7 were aligned from the indicated animals using ClustalX. The conserved cdk1/ cyclinB consensus sequence (S-P-X-K/R) and APC recognition motif D-box are illustrated. $(D)$ Western analysis for PR-Set7 and pS29-PR-Set7 on lysates from cells treated with vehicle DMSO, the cdk1 inhibitor CGP74514A, or the CKI inhibitor D4476. A general H4 antibody was used to control for loading. (E) Western analyses using the indicated antibodies were performed on cells transfected with a control shRNA or two different cyclinB shRNA plasmids. $(F)$ Recombinant wildtype PR-Set7 (WT) or N-terminal (amino acids 1-191) or C-terminal (amino acids 192-352) truncations was used as the substrate in in vitro kinase assays with purified cdk $1 /$ cyclinB. The reactions were fractionated by SDS-PAGE followed by autoradiography. $(G)$ Western analysis of in vitro kinase assays using wild-type PR-Set7 as the substrate and either cdk1/cyclinB or CKI. 
by endogenous kinases, a Flag-tagged PR-Set7 S29A mutant plasmid was transfected into HEK-293 cells, and the cell lysates were processed using the Qiagen Phosphoprotein Column as described above. In contrast to the wild-type Flag-PR-Set7, Western analysis revealed that the majority of the Flag-PR-Set7 S29A mutant protein was found in unbound flowthrough (Fig. 1B). These findings indicate that S29 is a major target for phosphorylation of PRSet7, and strongly suggest that this is mediated by cdk1/cyclinB. In addition, phylogenetic analysis of PR-Set7 demonstrated that this consensus sequence is highly conserved, suggesting a functional significance for this phosphorylation event (Fig. 1C).

\section{Cdk1/cyclinB complex specifically and selectively phosphorylates S29 of PR-Set7}

To determine if the cdk1/cyclinB complex is responsible for PR-Set7 S29 phosphorylation, three independent experimental approaches were performed. First, to determine if cdk1 or casein kinase I (CKI; which shares the same consensus site) phosphorylates S29 in vivo, HeLa cells were treated for $2 \mathrm{~h}$ with a cdk1-specific inhibitor (CGP74514A), a CKI inhibitor (D4476), or a DMSO vehicle control (Imbach et al. 1999). Western analysis of the cell lysates using a newly created rabbit polyclonal antibody that detects PR-Set7 only when S29 is phosphorylated (pS29-PR-Set7) (Supplemental Fig. 2) revealed that pS29-PR-Set7 was drastically reduced in the CGP74514Atreated cells compared to the vehicle control (Fig. 1D). In contrast, no visible reduction in phosphorylated S29 was observed in the presence of D4476 even with extended treatment times (data not shown). These findings indicate that cdk1, but not CKI, is required for PR-Set7 S29 phosphorylation in vivo.

Next, it was necessary to confirm that cyclinB is the bona fide regulatory factor for cdk1-mediated phosphorylation of PR-Set7 S29, since cdk1 is known to form catalytically active complexes with other cyclins (Satyanarayana and Kaldis 2009). To this end, HeLa cells were transfected with a control shRNA or two shRNA constructs that target different regions of cyclinB (cyclinB_1 and cyclinB_2). Western analysis of the cell lysates revealed that only the cyclinB_2 shRNA could deplete cells of cyclinB, whereas the cyclinB_1 shRNA had little to no effect (Fig. 1E). Importantly, a marked decrease of pS29-PR-Set7 in the cyclinB_2 shRNA cells was observed but not in the shRNA control or cyclinB_1 shRNA cells. These data indicate that the cdk1/cyclinB complex is specifically required for PR-Set7 S29 phosphorylation in vivo.

Last, to determine if cdk1/cyclinB can directly and specifically phosphorylate S29, in vitro kinase assays were performed using recombinant full-length or N-terminal or C-terminal truncations of PR-Set7 (amino acids 1-191 and 191-352, respectively) as substrates in the presence or absence of purified cdk1/cyclinB. The full-length and $\mathrm{N}$-terminal portion of PR-Set7, but not C-terminal, were phosphorylated in the presence of cdk1/cyclinB (Fig. 1F). To determine if S29 was the major phosphorylation site of cdk1/cyclinB, a PR-Set7 N-terminal S29A mutant was created and used as a substrate in the kinase assay. Consistent with our results above, the S29A mutant protein failed to be phosphorylated by cdkl/cyclinB in vitro (Fig. 1F). Importantly, CKI failed to phosphorylate PR-Set7 S29 despite sharing the consensus sequence (Fig. 1G). Collectively, these findings demonstrate that cdk1/cyclinB directly and predominantly phosphorylates S29 of PR-Set7.

\section{Phosphorylation of S29 does not affect PR-Set7 methyltransferase activity}

Since PR-Set7 functions to monomethylate histone H4K20, we hypothesized that S29 phosphorylation may affect PR-Set7 enzymatic activity. To test this directly, in vitro histone methyltransferase (HMT) assays were performed using ${ }^{3} \mathrm{H}$-SAM as the radiolabeled methyl donor, HeLa histones or nucleosomes as substrates, and either full-length recombinant PR-Set7 or recombinant PR-Set7 that was first phosphorylated by cdk1/cyclinB (Fig. 2A).
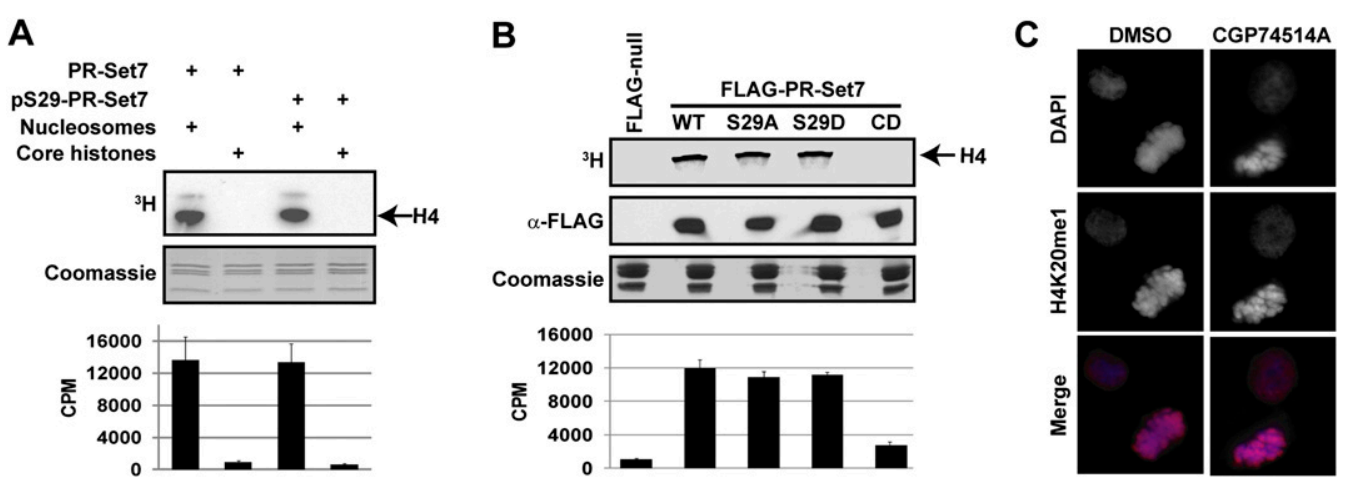

Figure 2. PR-Set7 methyltransferase activity is not altered by S29 phosphorylation. (A) HMT assays were performed using recombinant PR-Set7 or in vitro phosphorylated PR-Set7 on core histone or nucleosomal substrates and were analyzed by autoradiography or scintillation counting. Error bars represent standard deviation generated from three independent biological replicates. $(B)$ The indicated Flag-PR-Set7 fusion proteins were immunoprecipitated prior to an HMT assay using nucleosomal substrates and were analyzed by autoradiography or scintillation counting. Error bars represent standard deviation generated from three independent biological replicates. $(C)$ Cells treated with vehicle DMSO or the cdk1 inhibitor CGP74514A were immunostained with an H4K20me1-specific antibody (red) and counterstained with DAPI (blue). 
Wu et al.

Methyl incorporation was measured by autoradiography and scintillation counting. As shown in Figure 2A, core histones were not methylated by PR-Set7, as it is a nucleosome-specific methyltransferase (Nishioka et al. 2002). Nucleosomal substrates were methylated by S29-phosphorylated PR-Set7, but displayed no visible or significant differences compared with nonphosphorylated PR-Set7. To confirm this result, HeLa cells were transfected with either a Flag-tagged wild-type PR-Set7; the S29A mutant; an S29D mutant, which mimics phosphorylated serine; or an R265G catalytic-dead (CD) mutant. The purified Flag immunoprecipitates were examined for HMT activity using nucleosomal substrates. Similar to the above findings, the PR-Set7 wild-type, S29A mutant, and S29D mutant immunoprecipitates displayed no detectable or significant differences of $\mathrm{H} 4$ methylation, whereas the control and PR-Set7 CD immunoprecipitates failed to methylate H4 (Fig. 2B). Similar results were observed when p53 was used as a substrate (Supplemental Fig. 3; Shi et al. 2007). These findings indicate that S29 phosphorylation has no direct effect on PR-Set7 enzymatic function. To ensure that S29 phosphorylation would not indirectly affect PR-Set7 enzymatic activity in cells, HeLa cells were immunostained with an H4K20me1- specific antibody following incubation with the cdk 1 inhibitor (CGP74514A) or DMSO vehicle control. Similar staining levels of H4K20me1 were detected between the two samples at all phases in the cell cycle (Fig. 2C). Collectively, these findings demonstrate that cdk1/cyclinBmediated phosphorylation of S29 does not significantly alter PR-Set7 enzymatic function.

\section{Cdk1/cyclinB-mediated phosphorylation of PR-Set7 S29 occurs from prophase to anaphase}

Since the active cdk1/cyclinB complex is formed in late G2 and degraded in anaphase, we speculated that $\operatorname{cdk} 1 /$ cyclinB-mediated PR-Set7 S29 phosphorylation occurs at these times during mitosis. To test this, HeLa cells were synchronized at $\mathrm{G} 1 / \mathrm{S}$ by a thymidine-mimosine double block, released, and collected for Western analysis at specific time points in the cell cycle (Supplemental Fig. 4). Consistent with our previous results (Rice et al. 2002), PR-Set7 and H4K20me1 were lowest at S phase but gradually increased during cell cycle progression, reaching maximal levels at late G2 (Fig. 3A). In contrast to total PR-Set7, pS29-PR-Set7 was undetectable through S phase (although small amounts could be observed at longer
A

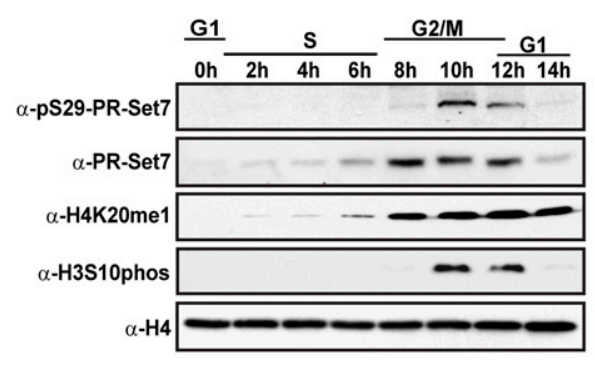

C

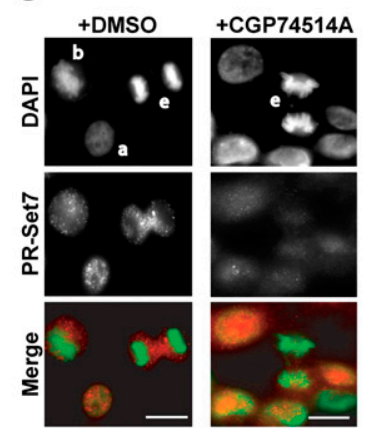

B

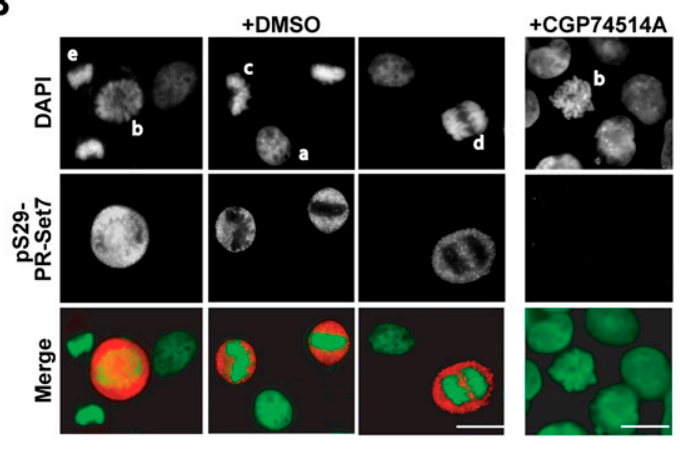

E MNase treatment $\frac{2 \mathrm{~min}}{\mathrm{~S} 1 \mathrm{~S} 2 \mathrm{P}} \frac{4 \mathrm{~min}}{\mathrm{~S} 1 \mathrm{~S} 2 \mathrm{P}} \frac{8 \mathrm{~min}}{\mathrm{~S} 1 \mathrm{~S} 2 \mathrm{P}}$

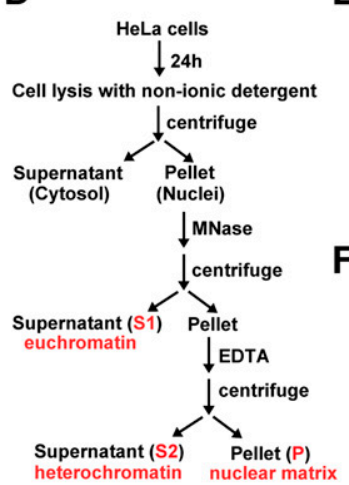

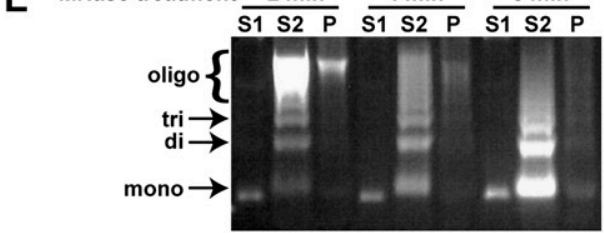

F MNase treatment $\quad 2 \mathrm{~min} \quad 4 \mathrm{~min} \quad 8 \mathrm{~min}$

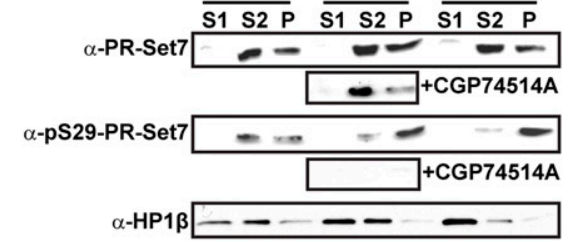

Figure 3. Phosphorylation of S29 during prophase to anaphase results in removal of PR-Set7 from mitotic chromosomes. (A) Western analysis of cells that were chemically arrested at G1/S, released, and collected at the indicated time points and corresponding cell cycle phases. $(B, C)$ Immunostaining using the pS29-PR-Set7 antibody $(B$, red) or PR-Set7 antibody $(C)$ in the presence of vehicle DMSO or cdk1 inhibitor CGP74514A. Counterstaining with DAPI (green) was used to identify cells in interphase $(a)$, prophase $(b)$, metaphase $(c)$, early anaphase $(d)$, and telophase $(e)$. Bar, $20 \mu \mathrm{m}$. (D) Flow chart of nuclear fractionation used to isolate euchromatin (S1), heterochromatin (S2), or insoluble chromatin (P). (E) Nuclei were digested with MNase for the indicated times prior to fractionation and DNA electrophoresis. The bands correspond to the expected sizes of mono-, di-, tri-, and oligonucleosomes. $(F)$ Western analysis of the different MNase-digested fractions from cells treated with or without the cdk1 inhibitor CGP74514A. 
exposures) (Supplemental Fig. 5), visible at G2, followed by a dramatic increase during $M$ that was rapidly reduced as the cells exited mitosis. Therefore, the majority of cdk1/cyclinB-mediated S29 phosphorylation occurs specifically during mitosis subsequent to the accumulation of PR-Set7 and global H4K20me1 in G2. To detail the precise phases of mitosis when PR-Set7 S29 phosphorylation occurs, HeLa cells were immunostained with PR-Set7 or pS29-PR-Set7 antibodies and counterstained with DAPI to visually determine cell cycle phase. Consistent with the other findings, pS29-PR-Set7 staining was restricted to mitotic cells (Fig. 3B) compared with PR-Set7 (Fig. 3C). Closer examination of the images revealed that pS29-PR-Set7 S29 was detected from prophase to early anaphase, but was greatly reduced by late anaphase and telophase (Fig. 3B, a-e). Importantly, in the presence of the cdk1 inhibitor (CGP74514A), pS29-PRSet7 was not detected in mitotic cells (Fig. 3B). Therefore, cdk1/cyclinB-mediated phosphorylation of PR-Set7 S29 occurs predominantly from prophase to early anaphase.

\section{PR-Set7 is removed from mitotic chromosomes} following S29 phosphorylation

Since PR-Set7 functions to methylate chromosomal histone H4K20, it remained unclear why pS29-PR-Set7 was paradoxically localized to the extrachromosomal space during metaphase and early anaphase (Fig. 3B, c,d). Since the bulk of H4K20me1 had already occurred at G2 (Fig. $3 \mathrm{~A})$, we hypothesized that the cdk1/cyclinB-mediated phosphorylation of PR-Set7 S29 may function to remove PR-Set7 from chromosomes during mitotic progression. If this were the case, then unphosphorylated PR-Set7 should be localized specifically to mitotic chromosomes. To test this, HeLa cells were treated with either the cdk1 inhibitor (CGP74514A) to block phosphorylation of S29, or DMSO vehicle control before staining for PR-Set7. While the majority of PR-Set7 was localized to the extrachromosomal space during mitosis in the control cells, similar to pS29-PR-Set7 (Fig. 3B), PR-Set7 was detected mainly on the chromosomes of mitotic cells in the absence of S29 phosphorylation (Fig. 3C; Supplemental Fig. 6). The reduction in PR-Set7 staining intensity in mitotic cells was most likely due to the abnormal enhanced degradation of PR-Set7 (see below). To confirm these findings biochemically, HeLa nuclei were partially digested with micrococcal nuclease (MNase) for 2, 4, or $8 \mathrm{~min}$ before isolating the various chromatin fractions (Fig. 3D; Wu et al. 2007). The MNase-sensitive soluble S1 fraction is composed of mono- and dinucleosomes typically associated with euchromatin, while the insoluble S2 fraction is composed of MNase-resistant oligonucleosomes typically associated with heterochromatin (Fig. 3E). The pellet (P) contains the material that remains bound to the nuclear matrix. With increased MNase digestion time, more of the $\mathrm{S} 2$ and $\mathrm{P}$ fractions become soluble and shift toward the S1 and S2 fractions, as observed with HP1 $\beta$ (Fig. 3F). Western analysis of these fractions revealed that PR-Set7 was enriched more within the heterochromatic S2 fraction than the P fraction but was not detected in the euchromatic S1 fraction, even at the longer MNase digestion times. In contrast, pS29-PRSet7 was present and remained highly associated with the $\mathrm{P}$ fraction at extended MNase digestion times, indicating that pS29-PR-Set7 is preferentially enriched within the nuclear matrix. Based on these findings, we speculated that the PR-Set7 detected within the P fraction was mainly composed of pS29-PR-Set7. To test this, the cells were treated with the cdk1 inhibitor (CGP74514A) prior to a 4-min MNase digestion and biochemical fractionation. Western analysis of these fractions demonstrated that the absence of S29 phosphorylation resulted in a near ablation of PR-Set7 in the P fraction (Fig. 3F). Collectively, these data indicate that PR-Set7 is preferentially targeted to heterochromatic regions, and that S29 phosphorylation results in the removal of PR-Set7 from mitotic chromosomes.

\section{Phosphorylation of S29 prevents PR-Set7 degradation}

Decreased PR-Set7 levels were consistently observed when S29 phosphorylation was inhibited, suggesting that phosphorylation of S29 may also function to stabilize PR-Set7 by preventing its degradation (Figs. 1D,E, 3C). To test this, the turnover of wild-type PR-Set7 was first examined in HeLa cells by monitoring its protein levels after inhibiting translation of new proteins using cyclohexamide (CHX). Western analysis demonstrated that PR-Set7 protein levels diminished rapidly within $1 \mathrm{~h}$ of CHX treatment; however, PR-Set7 degradation was ablated in the presence of the MG132 proteasome inhibitor (Fig. 4A). Interestingly, longer exposure of the Westerns revealed that degradation of PR-Set7 reached a plateau at the 5-h time point (Fig. 4B). Based on our hypothesis above, we speculated that the remaining PR-Set7 would be phosphorylated at S29. Western analysis performed on the same lysates demonstrated that pS29-PR-Set7 levels remained unchanged even after $7 \mathrm{~h}$ of $\mathrm{CHX}$ treatment. These results indicate that PR-Set7 is rapidly degraded, whereas pS29-PR-Set7 is highly resistant to degradation, and imply that the remaining PR-Set7 at the 5- to 7-h CHX plateau is pS29-PR-Set7. To determine if phosphorylation of S29 is required for preventing PR-Set7 degradation, HeLa cells were treated for $2 \mathrm{~h}$ with the DMSO vehicle control or the cdk1 inhibitor (CGP74515A) that depletes phosphorylated S29 prior to the addition of CHX (Fig 4C). While the rate of PR-Set7 degradation in the DMSO control cells was similar to the wild-type cells, the absence of phosphorylated S29 resulted in a visible decrease in PR-Set7 within 45 min of CHX treatment; PR-Set7 was undetectable by $90 \mathrm{~min}$. To confirm these findings, HeLa cells were transfected with a GFP-tagged wild-type PR-Set7, an S29A mutant, or an S29D mutant plasmid and visualized by GFP fluorescence. As expected, both the wild-type GFP-PR-Set7 and S29D phosphomimic displayed intense nuclear accumulation, whereas the S29A mutant signal was significantly weaker and, unexpectedly, was excluded from the nucleus (Fig. 4D,E). Importantly, treatment of the cells with the MG132 proteasome inhibitor rescued nuclear accumulation of 
A

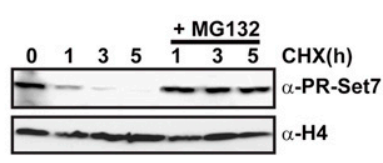

B

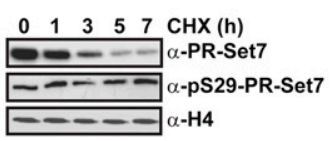

C

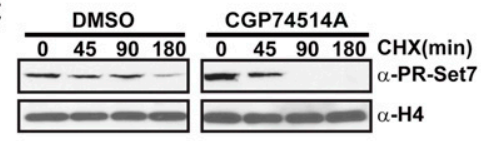

D

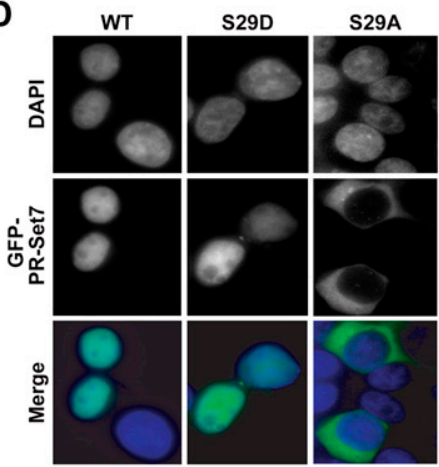

$E_{100 \%}$

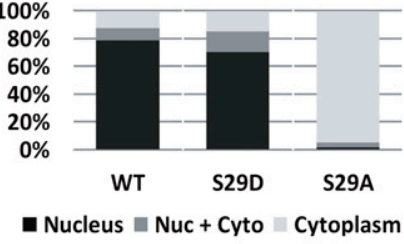

$\mathbf{F}$

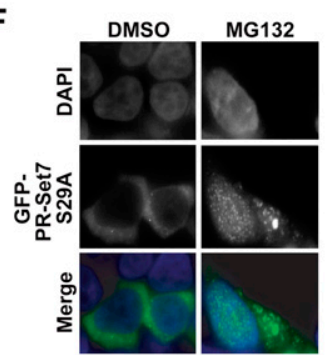

G

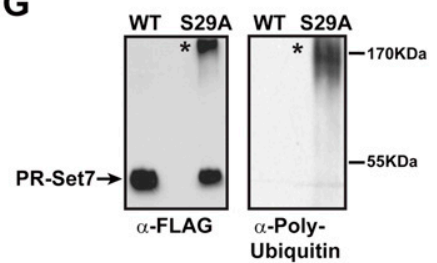

H

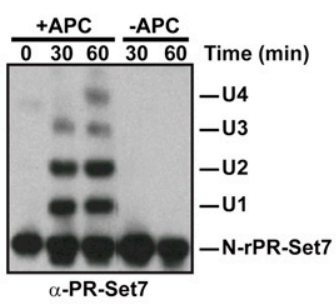

I

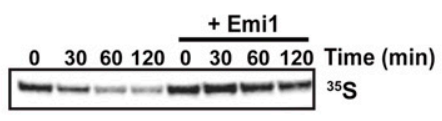

$J$

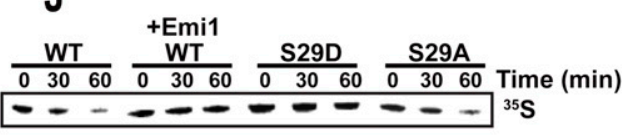

K

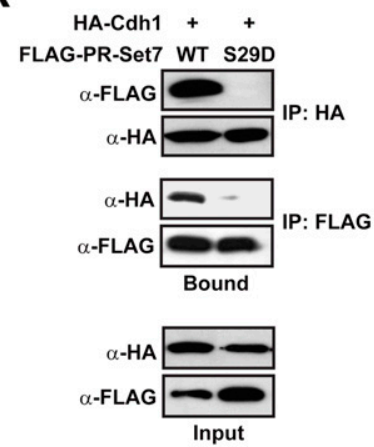

Figure 4. $\mathrm{APC}^{\mathrm{cdh} 1}$-mediated ubiquitination and degradation of PR-Set7 is directly inhibited by S29 phosphorylation. (A) Western analysis of cells treated with CHX for the indicated time points in the presence or absence of MG132. A general H4 antibody was used as a loading control. (B) Western analysis of cells treated with CHX for the indicated time points. $(C)$ Cells were treated with vehicle DMSO or cdk1 inhibitor CGP74514A prior to CHX treatment. Cells were collected at the indicated time points for Western analysis. $(D)$ Cells transfected with GFP-PRSet7 wild type, an S29A mutant, or an S29D phosphomimic mutant were counter stained with DAPI and visualized. $(E)$ Cellular distribution of the GFP fusion proteins from $D$ were determined in a blinded study of 200 random GFP-positive cells. (F) GFP-PR-Set7 S29A transfected cells were treated with vehicle DMSO or MG132 proteasome inhibitor and visualized. $(G)$ The indicated Flag-PR-Set7 fusion proteins were immunoprecipitated from cells, followed by Western analysis. The asterisk indicates polyubiquitinated PRSet7. $(H)$ Recombinant N-terminal PRSet7 (amino acids 1-191) was incubated \pm purified $\mathrm{APC}^{\mathrm{cdh} 1}$ at the indicated time points prior to Western analysis. Increasing degrees of PR-Set7 ubiquitination are shown. $(I, J)$ Autoradiography of ${ }^{35} \mathrm{~S}$-labeled wild-type PR-Set7 (I) or the S29A or S29D phosphomimic mutants $(J)$ incubated with HeLa G1 cell extracts at the indicated time points in the presence or absence of the APC inhibitor Emil. HeLa cells coexpressing HA-Cdh1 and Flag-PR-Set7 wildtype or S29D mutant were immunoprecipitated using either anti-HA or anti-Flag agarose beads. Western analysis of the input and bound material was performed using the indicated antibodies.
GFP-PR-Set7 S29A (Fig. 4F). Collectively, these findings indicate that PR-Set7 is rapidly degraded by the proteasome, and that S29 phosphorylation prevents the nuclear degradation of PR-Set7.

\section{S29 phosphorylation inhibits $A P C^{c d h 1}$-mediated ubiquitination and degradation of PR-Set7}

Western analysis of the Flag-tagged PR-Set7 fusion proteins revealed a high-molecular-weight smear detected only in the S29A mutant compared with the wild type, suggesting that it was preferentially ubiquitinated; this was confirmed using a ubiquitin antibody (Fig. 4G). This finding strongly suggested that the rapid degradation of PR-Set7 following anaphase was most likely due to ubiquitin-mediated proteolysis. Since the APC is an E3 ubiquitin ligase required for proteolysis of key mitotic regulators and completion of mitosis, we hypothesized that APC was responsible for PR-Set7 ubiquitination (Sullivan and Morgan 2007). Sequence analysis revealed that PR-Set7 contains a conserved D-box flanking S29, a stretch of amino acids recognized by APC, suggesting that APC ubiquitinates PR-Set7 (Fig. 1C). To test this in vitro, recombinant $\mathrm{N}$-terminal PR-Set7 that contains the D-box was incubated with or without purified APC ${ }^{\text {cdh1 }}$ (Supplemental Fig. 7), the predominant E3 ligase during anaphase through G1. Western analysis revealed that a ladder of higher-molecular-weight PR-Set7 was detected with increasing incubation times consistent with $\mathrm{APC}^{\mathrm{cdh} 1}$-mediated ubiquitination (Fig. 4H). To determine the effect of ubiquitination on PR-Set7 degradation, 
${ }^{35}$ S-labeled PR-Set7 was incubated for different times with early G1 HeLa S3 cell extracts that contain highly active APC ${ }^{\text {cdh } 1}$. Autoradiography demonstrated that ${ }^{35} \mathrm{~S}$ PR-Set7 was rapidly degraded, whereas the addition of the APC inhibitor Emil greatly reduced PR-Set7 degradation (Fig. 4I). Collectively, these findings indicate that proteolysis of PR-Set7 is mediated by the APC ${ }^{\text {cdh1 }}$ E3 ubiquitin ligase.

Based on our observations above, we hypothesized that phosphorylation of S29 could directly inhibit APC ${ }^{\text {cdh1 }}$. mediated ubiquitination of PR-Set7. To test this, an ${ }^{35} \mathrm{~S}$ labeled wild-type PR-Set7, an S29D phosphomimic mutant, or an S29A mutant was incubated at increasing times with the G1 HeLa cell extracts. Autoradiography revealed that the PR-Set7 S29A mutant was rapidly degraded, similar to wild-type PR-Set7 (Fig. 4J). However, proteolysis of the PR-Set7 S29D phosphomimic was nearly abolished, similar to Emil-treated PR-Set7. Since Cdh1 directly binds specific substrates for APC ${ }^{\mathrm{cdh} 1}-\mathrm{me}-$ diated ubiquitination, we speculated that the S29D mutant would be sufficient to inhibit Cdh1 binding to PRSet7 (Fang et al. 1998). To test this, an HA-tagged Cdh1 and a Flag-tagged PR-Set7 wild-type or S29D mutant were cotransfected into HeLa cells. Western analysis of the HA immunoprecipitates revealed a robust interaction of Cdh1 with wild-type Flag-PR-Set7, but interaction with the S29D mutant was not observed (Fig. 4K). In a reciprocal experiment, Western analysis of Flag immunoprecipitates confirmed that Cdh1 strongly and preferentially interacted with wild-type PR-Set 7 compared with the S29D mutant (Fig. 4K). These collective findings indicate that phosphorylation of S29 directly inhibits $\mathrm{APC}^{\mathrm{cdh} 1}$-mediated ubiquitination and degradation of PR-Set7.

\section{Cdc14 specifically and directly dephosphorylates PR-Set7 S29}

The findings above indicate that an unknown phosphatase is required to dephosphorylate S29 following anaphase for rapid $\mathrm{APC}^{\mathrm{cdh} 1}$-mediated ubiquitination and degradation of PR-Set7. The Cdc14 phosphatase preferentially dephosphorylates proteins that are modified by proline-directed kinases, such as $\operatorname{cdk} 1 /$ cyclinB, and plays a key role in mitotic exit, suggesting that it may dephosphorylate PR-Set7 (Kaiser et al. 2002; Mailand et al. 2002; Gray et al. 2003; Cho et al. 2005). Since mammals express two Cdc14 isoforms, Cdc14A and Cdc14B, whose specific substrates are poorly defined, it was necessary to investigate both isoforms (Li et al. 1997). To this end, an HA-tagged PR-Set7 was cotransfected into HeLa cells with either Flag-tagged Cdc14A or Cdc14B or their corresponding phosphatase-dead (PD) point mutants. Western analysis of HA immunoprecipitates demonstrated that both Cdc14A and Cdc14B robustly dephosphorylated S29 of PR-Set7, in contrast to the PD mutants or the negative control PTEN phosphatase (Fig. 5A). Furthermore, Western analysis of lysates from HeLa cells ectopically expressing the Flag-tagged Cdc14 proteins confirmed significant reductions in endogenous PR-Set7 S29 phosphorylation compared with the PD mutants and PTEN phosphatase (Fig. 5B). Interestingly, a slight
A

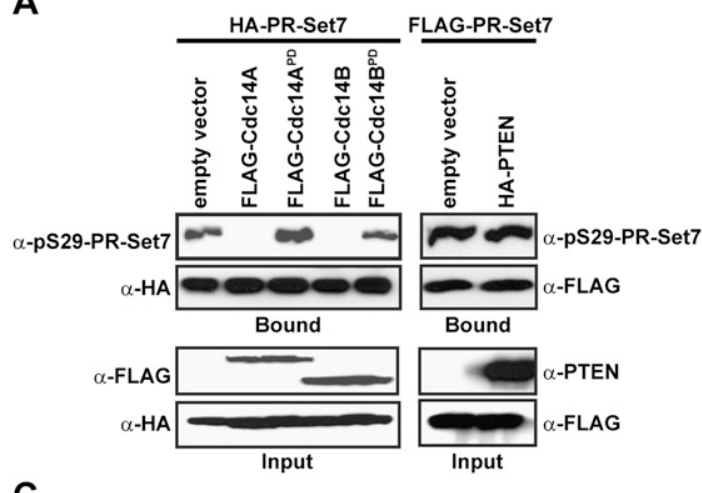

C

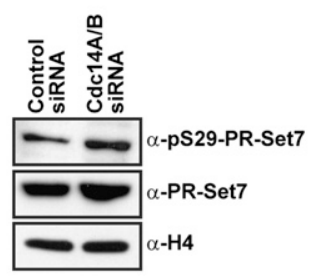

B

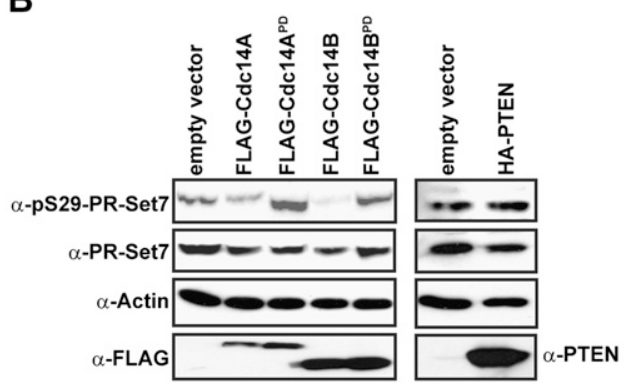

D

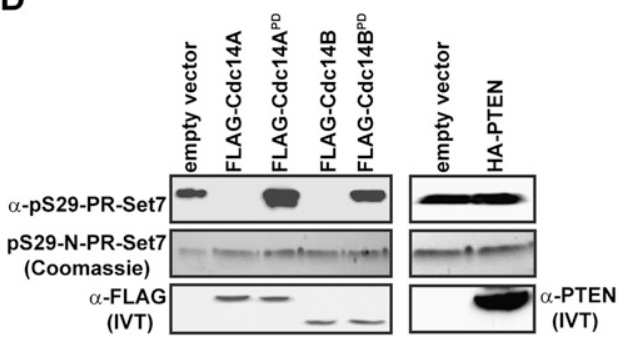

Figure 5. Dephosphorylation of PR-Set7 S29 by the Cdc14 phosphatases. (A) HeLa cells coexpressing HA-PR-Set7 and either FlagCdc14A, Cdc14B, or their corresponding PD mutants were immunoprecipitated using anti-HA agarose beads. Cells expressing Flag-PRSet7 and HA-PTEN were immunoprecipitated using anti-Flag agarose beads. Western analysis of the input and bound material was performed using the indicated antibodies. $(B)$ Western analysis of HeLa cells expressing various Flag-Cdc14 constructs or HA-PTEN. (C) Western analysis of HeLa cells treated with control siRNA or siRNA that reduced both Cdc14A and Cdc14B transcripts. (D) Dephosphorylation assays using in vitro phosphorylated N-terminal PR-Set7 as the substrate incubated with IVT Flag-Cdc14 proteins or HA-PTEN protein. Reactions were fractionated by SDS-PAGE, followed by Coomassie staining or Western analysis. 
reduction in total PR-Set7 levels was constantly detected in the wild-type Flag-Cdc14 lysates, consistent with the findings above, demonstrating that loss of S29 phosphorylation results in PR-Set7 degradation. Consistent with this, endogenous PR-Set7 and pS29-PR-Set7 were both elevated in HeLa cells simultaneously reduced of Cdc14A and Cdc14B by RNAi (Fig. 5C; Supplemental Fig. 8). To determine if Cdc14 could directly dephosphorylate S29 of PR-Set7, in vitro translated (IVT) Flag-tagged Cdc14A and Cdc14B plasmids and their corresponding PD point mutants were incubated with recombinant $\mathrm{N}$-terminal PR-Set7 phosphorylated at S29 (Fig. 1F). Western analysis of the reactions demonstrated that both Cdc14A and Cdc14B ablated S29 phosphorylation of PR-Set7, in contrast to the PD mutants and the PTEN phosphatase (Fig. 5D). These findings indicate that the Cdc14 phosphatases function directly to dephosphorylate PR-Set7 S29 in vitro and in vivo.

\section{Constitutive PR-Set7 S29 phosphorylation impedes mitotic progression}

The findings above suggest that the dynamic regulation of PR-Set7 during mitosis may be important for progression, similar to what was observed for other key cell cycle regulatory proteins. Therefore, we reasoned that the constitutive phosphorylation of PR-Set7 would inhibit its degradation, resulting in defective mitosis. We found previously that sustained ectopic expression of PR-Set7 induced a G2 arrest, most likely by altering H4K20me1 levels (Sims and Rice 2008). To avoid this phenotype and still be able to initially test the hypothesis, the Flagtagged wild-type PR-Set7, the degradation-resistant S29D phosphomimic, or the null control plasmid was transfected into HEK-293 cells $4 \mathrm{~h}$ prior to a 12 -h nocodazole treatment to induce a metaphase arrest. Cells were released into fresh media, and mitotic progression was monitored by flow cytometry (Supplemental Fig. 9). Within 30 min following release, the null and PR-Set7 wild-type cells could be detected entering G1 (Fig. 6A). By 60 min, $15 \%$ of the synchronized null and wild-type PR-Set7 cells had progressed to G1, but, in stark contrast, progression of the PR-Set7 S29D phosphomimic cells was significantly delayed; threefold less of these cells entered G1 at this time point compared with wild-type PR-Set7. At later times following release, however, the PR-Set7 S29D cells progressed to G1 with kinetics similar to those of the null and PR-Set7 wild-type cells. These findings indicate that expression of PR-Set7 S29D induces a significant mitotic delay, most likely by inhibiting entry to anaphase.
A

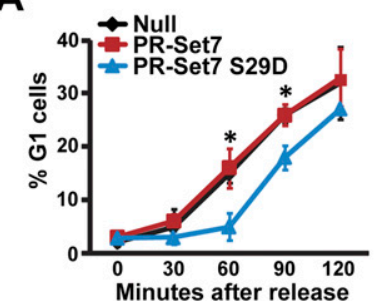

C

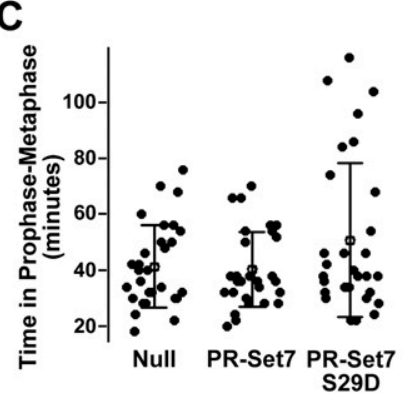

B

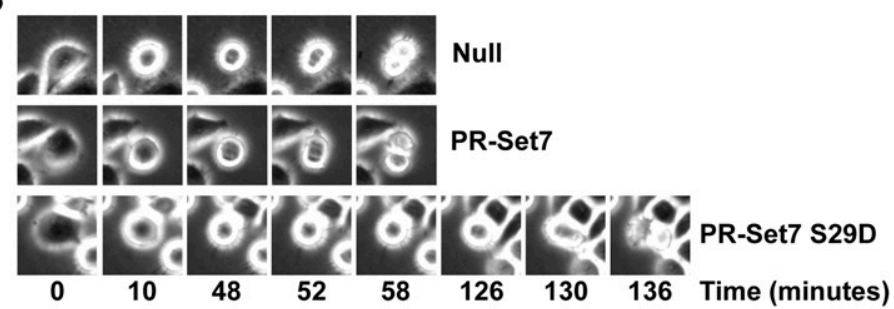

D

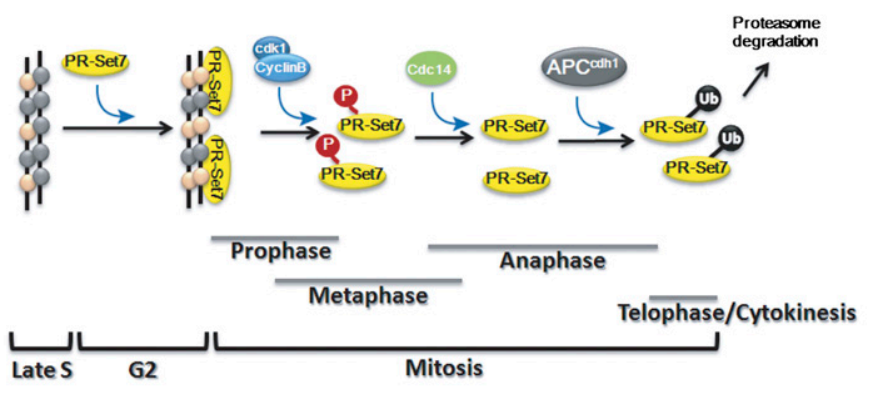

Figure 6. Sustained PR-Set7 S29 phosphorylation induces an early mitotic delay. (A) HEK-293 cells transfected with a Flag-PR-Set7, Flag-PR-Set7 S29D mutant, or null plasmid were arrested in metaphase by nocodazole and released. Flow cytometry of propidium iodide-stained cells was used to determine the percentage of released cells entering G1 ( $Y$-axis) at the indicated time points $(X$-axis). Error bars represent standard deviation from three independent replicates. The Student's $t$-test was used to determine statistical significance $\left(\left[{ }^{\star}\right] P<0.05\right)$. (B) Phase contrast images of released HeLa cells expressing the indicated proteins were recorded at 2-min intervals by live-cell imaging. Prophase cells were identified $(t=0)$. All cells achieved prometaphase by 10 min. The null and PR-Set7 wild-type cells exited metaphase $(t=48)$ and progressed through anaphase $(t=52)$ to cytokinesis $(t=58)$. The PR-Set7 S29D cell was delayed in early mitosis, exiting metaphase at $126 \mathrm{~min}$, but progressed normally thereafter. $(C)$ Time in prophase through metaphase (Y-axis) was determined for 30 cells from each group ( $X$-axis; black circles). Median values (open circles) and standard deviation are indicated. $(D)$ Proposed model for PR-Set7 regulation during cell cycle progression. The black line represents DNA, the grey circles are nucleosomes, and the pink circles depict H4K20me1. Following DNA replication, PR-Set7 accumulates at G2 to methylate H4K20 at specific heterochromatic loci. During prophase through metaphase, cdk1/cyclinB phosphorylates S29, resulting in the removal of PR-Set7 from mitotic chromosomes. PR-Set7 is rapidly dephosphorylated by the Cdc14 phosphatases during anaphase to release inhibition of $\mathrm{APC}^{\mathrm{cdh} 1}$-mediated ubiquitination, resulting in proteolysis of PR-Set7. 
To further investigate the mitotic delay, identical experiments were performed in HeLa cells in conjunction with live-cell imaging. Thirty cells entering prophase were identified visually from each group and photographed at 2-min intervals to record mitotic progression. Within 10-12 min, all cells had successfully achieved prometaphase (Fig. 6B). The null and PR-Set7 wild-type cells began to transition to anaphase within an average of $\sim 40 \mathrm{~min}$ (Fig. 6C). Although many of the PR-Set7 S29D cells displayed a similar pattern, we observed a distinct subpopulation of cells (eight of 30 ) that exhibited a prolonged prometaphase/metaphase (Fig. 6B). Nearly three times more of the PR-Set7 S29D cells failed to enter anaphase within 60 min compared with the control cells. Once anaphase was achieved, however, the PR-Set7 S29D cells progressed with kinetics similar to that of the control cells (Supplemental Fig. 10). Collectively, these findings indicate that constitutive phosphorylation of PR-Set7 results in a substantial delay to anaphase entry, strongly suggesting that the dynamic regulation of PR-Set7 is important for proper mitotic progression.

\section{Discussion}

This study illuminates the molecular mechanisms that govern the dynamic regulation of PR-Set7 during mitosis, and demonstrates that the orchestrated regulation of PR-Set7 is required for the correct timing of mammalian cell cycle progression. Previous reports and our new findings led us to propose a model of how PR-Set7 is regulated (Fig. 6D). PR-Set7 protein levels fluctuate dramatically during cell cycle progression, with the lowest levels observed during $S$ phase before peaking at G2/M (Rice et al. 2002). While this could be partially explained by modest changes in PR-Set7 transcription (Supplemental Fig. 4), our results indicate that PR-Set7 is regulated predominantly at the protein level, based on its short half-life. Consistent with this, we found that PR-Set7 is ubiquitinated by $\mathrm{APC}^{\mathrm{cdh} 1}$ during mitosis, resulting in proteolysis of PR-Set7. Interestingly, a recent study also determined that PR-Set7 ubiquitination by $\mathrm{SCF}^{\text {Skp2 }}$ and subsequent degradation of PR-Set7 at G1 were associated with S-phase entry (Yin et al. 2008). While the sustained decreased levels of PR-Set7 through S phase could be due to $\mathrm{SCF}^{\text {Skp2 }}$, it remains a formal possibility that other E3 ubiquitin ligases may also participate in the degradation of PR-Set7 during S-phase progression. These findings strongly suggest that the down-regulation of these ubiquitin ligases is largely responsible for the gradual but dramatic nuclear accumulation of PR-Set7 observed at G2.

During G2, we demonstrated that PR-Set7 is targeted primarily to specific heterochromatic regions of the genome, resulting in histone H4K20me1 (Congdon et al. 2010). Importantly, PR-Set7-mediated H4K20me1 is required for cell cycle progression, as ablation of H4K20me1 results in a G2 arrest. The few cells that escape this arrest are marked by global decondensed chromatin associated with aberrant chromosomal segregation defects that could result in aneuploidy and oncogenesis
(Karachentsev et al. 2005; Houston et al. 2008). It was shown previously that the MBT repeats of the L3MBTL1 protein bind H4K20me1, resulting in chromatin condensation in vitro (Trojer et al. 2007), and mutations in these MBT repeats correlate with mitotic defects in Drosophila (Yohn et al. 2003). In addition, a recent report showed that N-CAPD3 and N-CAPG2, subunits of the condensin II complex, also selectively bind H4K20me1 via their HEAT repeats (Liu et al. 2010). These findings strongly suggest that PR-Set7-mediated H4K20me1 during G2/M functions primarily to recruit chromatin condensationpromoting complexes, such as condensin II and L3MBTL1, to ensure the proper timing of mitotic progression. Although these hypotheses have yet to be validated experimentally, our data clearly demonstrate that the accumulation of PR-Set7 on mitotic chromosomes is required for H4K20me1 and normal mitotic progression.

During prophase through early anaphase, we discovered that PR-Set7 is phosphorylated specifically at S29 by the cdk1/cyclinB complex. We observed that one striking consequence of S29 phosphorylation was the removal of PR-Set7 from mitotic chromosomes, although the mechanisms responsible for this remain unknown. There are several possibilities, including that S29 phosphorylation could physically decrease the affinity of PR-Set7 for chromatin and/or the phosphorylation of S29 could create a binding site for an unidentified protein complex that actively transports PR-Set7 from chromosomes. Alternatively, the phosphorylation of S29 could potentially inhibit PR-Set7 interaction with an unknown protein complex required for its recruitment to chromatin. These possibilities are currently being investigated. Regardless, our findings strongly suggest that the removal of PR-Set7 from chromosomes by cdk1/cyclinB-mediated phosphorylation during early mitosis may be critical for proper cell cycle progression. The removal of PR-Set7 may be required to expose the H4K20mel modification in order to permit the binding of the large condensin II complex, thereby promoting the assembly of condensed chromosomes and mitotic progression.

During anaphase through to G1, we discovered that the observed decrease in PR-Set7 was directly due to $\mathrm{APC}^{\mathrm{cdh} 1}$-mediated ubiquitination and subsequent proteolysis of PR-Set7. Interestingly, we found that S29 phosphorylation inhibits Cdh1 interaction with PR-Set7, thereby preventing PR-Set7 ubiquitination and degradation during late mitosis. Due to the close proximity of the D-box, it is possible that PR-Set7 S29 phosphorylation could directly inhibit Cdh1 interaction. Since phosphorylated PR-Set7 is present in early mitosis, it is highly likely that similar mechanisms prevent PR-Set7 ubiquitination by $\mathrm{APC}^{\text {cdc20 }}$. Alternatively, S29 phosphorylation-dependent binding of the postulated protein complex responsible for removing PR-Set7 from chromosomes (see above) may indirectly inhibit Cdh1 interaction.

The activation of $\mathrm{APC}^{\mathrm{cdh} 1}$ at anaphase requires the dephosphorylation of Cdh1 by the Cdc14 phosphatase (Visintin et al. 1998). We found that S29 was also dephosphorylated by either Cdc14A or Cdc14B, ultimately resulting in $\mathrm{APC}^{\mathrm{cdh} 1}$-mediated ubiquitination 
and proteolysis of PR-Set7. Since the dephosphorylation and degradation of PR-Set7 seemed to occur later in mitosis, we hypothesized that the degradation-resistant PR-Set7 S29D phosphomimic would display defects in anaphase and/or cytokinesis. Consistent with this, a substantial delay in progression to anaphase was observed in the PR-Set7 S29D cells compared with wild-type PR-Set7 cells. Since the wild-type PR-Set7 cells behaved similarly to control cells during mitosis, the observed delay to anaphase entry is most likely due to elevated levels of "phosphorylated" PR-Set7 rather than increased levels of bulk PR-Set7. However, once the PR-Set7 S29D cells eventually achieved anaphase, they displayed progression kinetics similar to that of the control cells. Our collective findings indicate that the dynamic regulation of PR-Set7 is required for normal mitosis, and that constitutive phosphorylation of PR-Set7 is refractory for progression to anaphase.

\section{Materials and methods}

\section{Phosphoprotein purification}

Qiagen Phosphoprotein Purification columns were used to isolate phosphoproteins according to the manufacturer's protocol. Briefly, whole-cell extracts from $10^{7}$ HEK-293 cells were collected, adjusted to $0.1 \mathrm{mg} / \mathrm{mL}$, and passed through the column; flowthrough was collected and concentrated by TCA precipitation. Following several washes, the bound material was eluted for Western analysis.

\section{Plasmids}

Full-length PR-Set7 (NP065115) was cloned into the pcDNA4Flag (Invitrogen) and pSG5-Flag (Stratagene) vectors. Mutants were created using the QuickChange II Site-Directed Mutagenesis kit according to the manufacturer's protocol (Stratagene). CyclinB shRNAs were purchased from Open Biosystems: null (RHS4080), cyclinB_1 (RHS3979-9612503), and cyclinB_2 (RHS3979-9612505). pcDNA3.0-Flag-hCdc14 plasmids were obtained from Dr. Sylvain Meloche (Tanguay et al. 2010). The pSG5-PTEN plasmid was obtained from Dr. Bangyan Stiles (University of Southern California).

\section{In vitro kinase assay}

Recombinant PR-Set7 was purchased from Active Motif. N-terminal PR-Set7 (1-191 amino acids) was cloned into the pET45b(+) vector (Novagen), and the pHIS2-PR-Set7 (191-352 amino acids) was obtained from Dr. Raymond Trievel (Couture et al. 2005). Proteins were induced in BL21 Escherichia coli (Novagen) and purified using Ni-Sepharose high-performance beads (GE). For kinase assays, $1 \mu \mathrm{g}$ of the purified protein was incubated with $20 \mathrm{U}$ of Cdk1/cyclinB (New England Biolabs) and $0.4 \mathrm{mM}{ }^{32} \mathrm{P}$-ATP in a final volume of $30 \mu \mathrm{L}$ for $30 \mathrm{~min}$ at $30^{\circ} \mathrm{C}$. Reactions were terminated by adding $6 \times$ SDS load dye prior to fractionation by SDS-PAGE and autoradiography.

\section{Western analysis}

Western analysis was performed as described previously (Sims and Rice 2008). For the following antibodies, 1-h room temperature incubations were performed: Flag M2 (1:5000; Sigma), HA (1:2000; Santa Cruz Biotechnology), polyubiquitin (1:1000;
Covance), UBC9 (1:5000; Santa Cruz Biotechnotogy), H4K20me1 (1:8000; Active Motif), H3S10phos (1:25,000; Abcam), H4 general (1:60,000; Abcam), cyclinB (1:1000; Santa Cruz Biotechnology), GFP (1:10,000; Abcam), $\beta$-actin (1:40,000; Sigma), and HP1 $\beta$ (1:5000; Sigma). The pS29-PR-Set7 antibody was incubated at 1:1000 for $3 \mathrm{~h}$ at room temperature. The PR-Set7 and PTEN antibodies (Cell Signaling) were incubated at 1:1000 overnight at $4^{\circ} \mathrm{C}$.

\section{Cell culture and drug treatment}

HeLa and HEK-293 cells (American Type Culture Collection) were cultured as described previously (Sims et al. 2006). Cells were incubated with $1 \mu \mathrm{M}$ CGP74514A or $50 \mu \mathrm{M}$ D4476 for $2 \mathrm{~h}$ (Sigma). Cells were treated with $100 \mu \mathrm{g} / \mathrm{mL}$ CHX(Calbiochem) for different times in the absence or presence of $25 \mu \mathrm{g} / \mathrm{mL}$ MG132 (Sigma). In all cases, the final DMSO concentration was $<0.1 \%$ to minimize toxicity.

\section{Immunofluorescence}

HeLa cells were treated with cdk1 inhibitor CGP74514A for $2 \mathrm{~h}$ or MG132 for $6 \mathrm{~h}$ before being fixed and stained as described previously (Rice et al. 2003). Antibody dilutions used were as follows: PR-Set7 (1:50; Cell Signaling), pS29-PR-Set7 (1:100), H4K20me1 (1:1000; Active Motif). Staining was visualized using a $63 \times$ objective on a Zeiss Axio Imager upright fluorescence microscope with ApoTome. Images were analyzed using Adobe PhotoShop CS2.

\section{APC ubiquitination and degradation assays}

APC $^{\text {cdh1 }}$ was purified from early G1 HeLa S3 cell extracts (Supplemental Fig. 7), and ubiquitination assays were performed as described previously (Rape et al. 2006). Briefly, $0.05 \mathrm{mg} / \mathrm{mL}$ recombinant PR-Set7 was incubated with $30 \mathrm{nM}$ purified $\mathrm{APC}^{\mathrm{cdh} 1}, 0.05 \mu \mathrm{M} \mathrm{E} 1,1 \mu \mathrm{M} \mathrm{E} 2$ (UBCH10), and $1 \mathrm{mg} / \mathrm{mL}$ ubiquitin for $30 \mathrm{~min}$ and $60 \mathrm{~min}$ prior to Western analysis. For the degradation assays, early G1 HeLa S3 extracts were added to ${ }^{35}$ S-labeded full-length PR-Set7 wild type, S29A mutant, or S29D mutant in the absence or presence of $0.25 \mathrm{mg} / \mathrm{mL}$ APC inhibitor Emil. Reactions were fractionated by SDS-PAGE and visualized by autoradiography.

\section{HMT assays}

HMT assays were performed as described previously (Nishioka et al. 2002). Briefly, $1 \mu \mathrm{g}$ of rPR-Set7 or Flag-PR-Set7 immunoprecipitates was incubated for $1 \mathrm{~h}$ at $37^{\circ} \mathrm{C}$ with $1 \mu \mathrm{g}$ of HeLa core histones or nucleosomes and $1 \mu \mathrm{M}^{3} \mathrm{H}$-SAM (MP Biomedicals) in reaction buffer containing $50 \mathrm{mM}$ Tris $(\mathrm{pH} 8.0), 10 \%$ glycerol, $1 \mathrm{mM}$ DTT, and $1 \mathrm{mM}$ PMSF. Half the reaction was fractionated by SDS-PAGE and visualized by autoradiography, while the other half was spotted on P-81 filter paper, washed, and measured by scintillation counting.

\section{In vitro dephosphorylation assay}

Flag-Cdc14 or HA-PTEN proteins were prepared using TNT quick-coupled transcription/translation system (Promega). One microgram of in vitro phosphorylated N-terminal PR-Set7 was incubated with the IVT Cdc14 or PTEN proteins for $30 \mathrm{~min}$ at $30^{\circ} \mathrm{C}$ in a final volume of $30 \mu \mathrm{L}$ of reaction buffer $(200 \mathrm{mM}$ Tris- $\mathrm{HCl}$ at $\mathrm{pH} 7.5,100 \mathrm{mM} \mathrm{NaCl}, 1 \mathrm{mM} \mathrm{DTT}$ ). Reactions were terminated by adding $6 \times$ SDS load dye and were fractionated 
by SDS-PAGE, followed by either autoradiography or Western analysis.

\section{Flow cytometry and live-cell imaging}

Four hours following transfection into HEK-293 or HeLa, cells were arrested with $400 \mathrm{ng} / \mathrm{mL}$ nocodazole (Sigma) for $12 \mathrm{~h}$. Cells were washed thoroughly, released into fresh media, collected at various time points, and fixed with ethanol for analysis by flow cytometry (Houston et al. 2008). For imaging, 30 cells in G2 from each group were identified visually. Phase contrast images were acquired at 2-min intervals to record mitotic progression.

\section{Acknowledgments}

We are grateful to Drs. Raymond Trievel (University of Michigan), Sylvain Meloche (University of Montreal), and Bangyan Stiles (University of Southern California) for providing reagents. We thank Sabrina Houston for early technical contributions, Daniel Newkirk (University of California at Irvine) for graphic assistance, and Dr. Dawn Clifford (Grand Valley State University) for insights into Cdc14. This work was supported by Pew Charitable Trusts (to J.C.R), the Wang Predoctoral Award (to S.W.) and the NIH (GM075094 to J.C.R., GM039023 to M.W.K., and AR058548 to K.Y.).

\section{References}

Biron VL, McManus KJ, Hu N, Hendzel MJ, Underhill DA. 2004. Distinct dynamics and distribution of histone methyllysine derivatives in mouse development. Dev Biol 276: 337-351.

Cho HP, Liu Y, Gomez M, Dunlap J, Tyers M, Wang Y. 2005. The dual-specificity phosphatase CDC14B bundles and stabilizes microtubules. Mol Cell Biol 25: 4541-4551.

Congdon LM, Houston SI, Veerappan CS, Spektor TM, Rice JC. 2010. PR-Set7-mediated monomethylation of histone $\mathrm{H} 4$ lysine 20 at specific genomic regions induces transcriptional repression. J Cell Biochem 110: 609-619.

Couture JF, Collazo E, Brunzelle JS, Trievel RC. 2005. Structural and functional analysis of SET8, a histone H4 Lys-20 methyltransferase. Genes Dev 19: 1455-1465.

Fang G, Yu H, Kirschner MW. 1998. Direct binding of CDC20 protein family members activates the anaphase-promoting complex in mitosis and G1. Mol Cell 2: 163-171.

Fang J, Feng Q, Ketel CS, Wang H, Cao R, Xia L, ErdjumentBromage H, Tempst P, Simon JA, Zhang Y. 2002. Purification and functional characterization of SET8, a nucleosomal histone H4-lysine 20-specific methyltransferase. Curr Biol 12: $1086-1099$.

Gray CH, Good VM, Tonks NK, Barford D. 2003. The structure of the cell cycle protein Cdc14 reveals a proline-directed protein phosphatase. EMBO I 22: 3524-3535.

Houston SI, McManus KJ, Adams MM, Sims JK, Carpenter PB, Hendzel MJ, Rice JC. 2008. Catalytic function of the PR-Set7 histone H4 lysine 20 monomethyltransferase is essential for mitotic entry and genomic stability. I Biol Chem 283: 19478-19488.

Huen MS, Sy SM, van Deursen JM, Chen J. 2008. Direct interaction between SET8 and PCNA couples H4-K20 methylation with DNA replication. I Biol Chem 283: 1107311077.

Imbach P, Capraro HG, Furet P, Mett H, Meyer T, Zimmermann J. 1999. 2,6,9-Trisubstituted purines: Optimization towards highly potent and selective CDK1 inhibitors. Bioorg Med Chem Lett 9: 91-96.
Jorgensen S, Elvers I, Trelle MB, Menzel T, Eskildsen M, Jensen ON, Helleday T, Helin K, Sorensen CS. 2007. The histone methyltransferase SET8 is required for S-phase progression. J Cell Biol 179: 1337-1345.

Kaiser BK, Zimmerman ZA, Charbonneau H, Jackson PK. 2002. Disruption of centrosome structure, chromosome segregation, and cytokinesis by misexpression of human Cdc14A phosphatase. Mol Biol Cell 13: 2289-2300.

Kalakonda N, Fischle W, Boccuni P, Gurvich N, Hoya-Arias R, Zhao X, Miyata Y, Macgrogan D, Zhang J, Sims JK, et al. 2008. Histone H4 lysine 20 monomethylation promotes transcriptional repression by L3MBTL1. Oncogene 27: 42934304.

Karachentsev D, Sarma K, Reinberg D, Steward R. 2005. PRSet7-dependent methylation of histone H4 Lys 20 functions in repression of gene expression and is essential for mitosis. Genes Dev 19: 431-435.

Li L, Ernsting BR, Wishart MJ, Lohse DL, Dixon JE. 1997. A family of putative tumor suppressors is structurally and functionally conserved in humans and yeast. $J$ Biol Chem 272: 29403-29406.

Liu W, Tanasa B, Tyurina OV, Zhou TY, Gassmann R, Liu WT, Ohgi KA, Benner C, Garcia-Bassets I, Aggarwal AK, et al. 2010. PHF8 mediates histone H4 lysine 20 demethylation events involved in cell cycle progression. Nature 466: 508512.

Mailand N, Lukas C, Kaiser BK, Jackson PK, Bartek J, Lukas J. 2002. Deregulated human Cdc14A phosphatase disrupts centrosome separation and chromosome segregation. Nat Cell Biol 4: 317-322.

Nishioka K, Rice JC, Sarma K, Erdjument-Bromage H, Werner J, Wang Y, Chuikov S, Valenzuela P, Tempst P, Steward R, et al. 2002. PR-Set7 is a nucleosome-specific methyltransferase that modifies lysine 20 of histone $\mathrm{H} 4$ and is associated with silent chromatin. Mol Cell 9: 1201-1213.

Oda H, Okamoto I, Murphy N, Chu J, Price SM, Shen MM, Torres-Padilla ME, Heard E, Reinberg D. 2009. Monomethylation of histone H4-lysine 20 is involved in chromosome structure and stability and is essential for mouse development. Mol Cell Biol 29: 2278-2295.

Peters JM. 2006. The anaphase promoting complex/cyclosome: A machine designed to destroy. Nat Rev Mol Cell Biol 7: 644-656.

Rape M, Reddy SK, Kirschner MW. 2006. The processivity of multiubiquitination by the APC determines the order of substrate degradation. Cell 124: 89-103.

Rice JC, Nishioka K, Sarma K, Steward R, Reinberg D, Allis CD. 2002. Mitotic-specific methylation of histone H4 Lys 20 follows increased PR- Set7 expression and its localization to mitotic chromosomes. Genes Dev 16: 2225-2230.

Rice JC, Briggs SD, Ueberheide B, Barber CM, Shabanowitz J, Hunt DF, Shinkai Y, Allis CD. 2003. Histone methyltransferases direct different degrees of methylation to define distinct chromatin domains. Mol Cell 12: 1591-1598.

Satyanarayana A, Kaldis P. 2009. Mammalian cell-cycle regulation: Several Cdks, numerous cyclins and diverse compensatory mechanisms. Oncogene 28: 2925-2939.

Shi X, Kachirskaia I, Yamaguchi H, West LE, Wen H, Wang EW, Dutta S, Appella E, Gozani O. 2007. Modulation of p53 function by SET8-mediated methylation at lysine 382. Mol Cell 27: 636-646.

Sims JK, Rice JC. 2008. PR-Set7 establishes a repressive transtail histone code that regulates differentiation. Mol Cell Biol 283: 19478-19488.

Sims JK, Houston SI, Magazinnik T, Rice JC. 2006. A trans-tail histone code defined by monomethylated $\mathrm{H} 4$ Lys- 20 and $\mathrm{H} 3$ 
Wu et al.

Lys-9 demarcates distinct regions of silent chromatin. J Biol Chem 281: 12760-12766.

Stukenberg PT, Lustig KD, McGarry TJ, King RW, Kuang J, Kirschner MW. 1997. Systematic identification of mitotic phosphoproteins. Curr Biol 7: 338-348.

Sullivan M, Morgan DO. 2007. Finishing mitosis, one step at a time. Nat Rev Mol Cell Biol 8: 894-903.

Tanguay PL, Rodier G, Meloche S. 2010. C-terminal domain phosphorylation of ERK3 controlled by Cdk1 and Cdc14 regulates its stability in mitosis. Biochem J 428: 103-111.

Tardat M, Murr R, Herceg Z, Sardet C, Julien E. 2007. PR-Set7-dependent lysine methylation ensures genome replication and stability through S phase. J Cell Biol 179: 1413-1426.

Thornton BR, Toczyski DP. 2006. Precise destruction: An emerging picture of the APC. Genes Dev 20: 3069-3078.

Trojer P, Li G, Sims RJ III, Vaquero A, Kalakonda N, Boccuni P, Lee D, Erdjument-Bromage H, Tempst P, Nimer SD, et al. 2007. L3MBTL1, a histone-methylation-dependent chromatin lock. Cell 129: 915-928.

Visintin R, Craig K, Hwang ES, Prinz S, Tyers M, Amon A. 1998. The phosphatase Cdc14 triggers mitotic exit by reversal of Cdk-dependent phosphorylation. Mol Cell 2: 709-718.

Wu S, Trievel RC, Rice JC. 2007. Human SFMBT is a transcriptional repressor protein that selectively binds the $\mathrm{N}$-terminal tail of histone H3. FEBS Lett 581: 3289-3296.

Yin Y, Yu VC, Zhu G, Chang DC. 2008. SET8 plays a role in controlling G1/S transition by blocking lysine acetylation in histone through binding to $\mathrm{H} 4 \mathrm{~N}$-terminal tail. Cell Cycle 7: 1423-1432.

Yohn CB, Pusateri L, Barbosa V, Lehmann R. 2003. 1(3)malignant brain tumor and three novel genes are required for Drosophila germ-cell formation. Genetics 165: 1889-1900. 


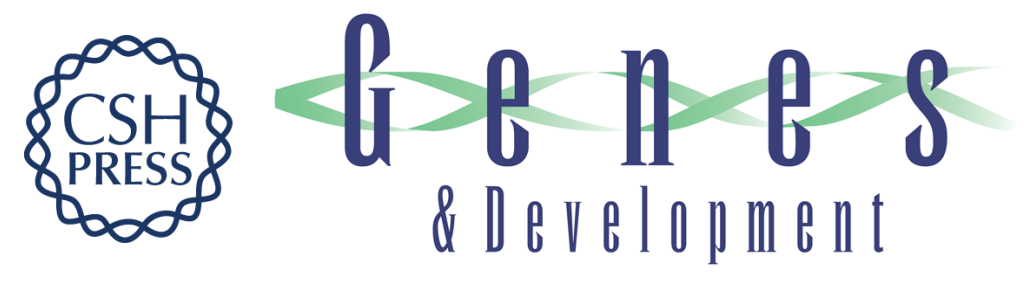

\section{Dynamic regulation of the PR-Set7 histone methyltransferase is required for normal cell cycle progression}

Shumin Wu, Weiping Wang, Xiangduo Kong, et al.

Genes Dev. 2010, 24: originally published online October 21, 2010

Access the most recent version at doi:10.1101/gad.1984210

\section{Supplemental http://genesdev.cshlp.org/content/suppl/2010/10/15/gad.1984210.DC1 Material}

References This article cites 37 articles, 15 of which can be accessed free at: http://genesdev.cshlp.org/content/24/22/2531.full.html\#ref-list-1

\section{License}

Email Alerting

Receive free email alerts when new articles cite this article - sign up in the box at the top Service

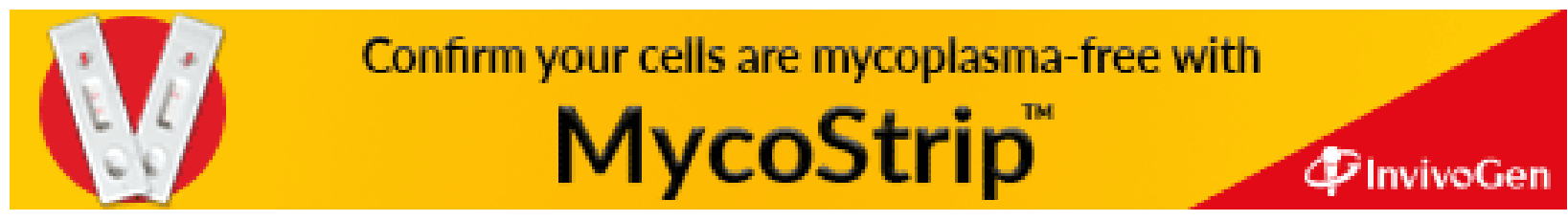

